\title{
The Ethics of Warfare
}

\section{W. V. Herbert Late Captain, Turkish Army Esq.}

To cite this article: W. V. Herbert Late Captain, Turkish Army Esq. (1898) The Ethics of Warfare, Royal United Services Institution. Journal, 42:247, 1021-1033, DOI: $\underline{10.1080 / 03071849809417404}$

To link to this article: http://dx.doi.org/10.1080/03071849809417404

\section{册 Published online: 11 Sep 2009.}

Submit your article to this journal $\pi$

ЦIl Article views: 8

Q View related articles $\sqsubset$ 


\title{
THE EI KOBSESTF IVARFARE.
}

\section{By IV. V. HERIBERT, Esq. (late Caplain, Turkish Army.)}

\author{
Wednesdlay, February 23rd, 1898.
}

Colonel Lonsdate A. Hale, late R.E., in the Chair.

The Crammax :-Gentlenen, last year Captain Herbert was kind enough to give us a lecture upon "The P gchology of the Battle-field," a lecture which was delivered to an audience con iratively small, but which has been read by many menbers of the Institution, and has been thoroughly appreciated. I am sure you will allow me on your behalf to welcome Captain Herbert back agrain to read to us another paper, the subject of which is "The Ethics of Warfare."

\section{LECTURE.}

SOME kindly critic pointed out to me that the title of my last lecture from this platform of honour and distinction was an incongruity and a misnomer. A heading, "The Psychology of the Battle-field"-so he saysimplies a system of psychology relating to that particular phase of human existence, after the analogy of Kant's system of philosophy of the human reason; whereas what I presented was various phases of psychology with much kindred or half-related matter. Granted; I plead guilty. In the same manner, kindly do not look to-day for a complete system of the ethics of that particular condition of liuman existence called warfare. What I am about to present to you is a few ethical aspects of war, interwoven with much other matter appertaining or distantly related thereto. But I prefer the shorter title; brevity of head-line always charms an author. What I intended to present to you last year, and what I mean to tender to you to-diay, are, not systems of any "ology," however abstruse, complicated, and le ued; but merely that which is instructive and (this is the chief point, uggestive of further research or reflection; sometimes, rarely, also that which is amtsing. But in connection with amusing matter, I beg of you not to take any flash of humour of him, or of anyone else, however feeble, as a serious argument. It is very hurtful. I find it necessary to say this, becausc, incredible as it may seem, a very weak joke of mine in the "Defence of Plevna" has been taken as serious by more than one reviewer. In speaking of the vagrant dogs of Turkéy, I wrote:- "They have an organisation of their own, which is quite as wonderful and a good deal more sensible than the British Constitution." -Would you believe it? I ha:e been seriously taken to task for that, not as a joke, but as sober sense!

I topose to divide this very modest contribution to a rast subject, which could be casily expanded into a many-volumed philosophy of warfarc, into two components. I shall simply state the arguments pro VOI. XLII. 
and the arguments contra, the ethical view of warfare, the view that war, being not only a concomitant of the life of the human race, but an advantageous and, to a certain extent, even ennobling one, like art or science, can and should, like art.or science, be subjected to certain ethical rules; for the existence of an ethical aspect proved, the greater and more serious question enters of the wisdom, or otherwise, of obedience to an ethical code.

To begin with a crucle definition : ethics is the science that treats of human actions as springing from mental affections; ethics is therefore a part of moral philosophy. In the commonly accepted sense, the ethical side of any question is that side which deals with the moral concomitants, and-to widen the definition by an easy logical step, as is commonly done-that side which deals with man's inherent and unconscious aspiration towards the beautiful or the perfect. It is in the nature of the human intellect to import an ethical side into most questions that affect the human race, even into disagrecable ones, to mention an instance: - the institution of marriage, which is hedred round with a perfect system of ethics. "Then, if an ethical side to domestic warfare, why not to national war?-but that I do not advance as an argument, though it is perfectly pertinent. Now, the primary question which obstructs our argument is this: Is there an ethical side to warfare? is such a one possible? I do not mean possible to the professional philosopher, who will argue a soul into the stone, and beaty into the earthworm, but to the ordinary fight-your-daily-battle individual like you and me, and more particularly to those to whom warfare is, or lhas been, or might become, the means of buying bread and cheesc.

Is there an ethical side to warfare? Is there an ethical side to crime?-I hear the peace-at-any-price politician ask. Here I maintitin that war and crime are not parallels. War is not to the nation what crime is to the individual. The whole of known history disproves it. Crime is not a concomitant of human life, but is the consequence of an alienation of the human will. - History proves that war is a necessity of human existence. Do not many nations, most nations, owe their very existence to war? Even Switzerland, the most peaceful of nations, has had her little wars, one only as recently as 18.7 (the Gislikon revolt). One can well imagine human existence without crime, but not national existence without initial wars.

I have another proof that war and crime are not parallels in their relations to nation and individual. The conception of war has remained unaltered since man first learnt to make and carry arms, though its conduct has changed beyond the recognition of an old-world soldier. The conception of crime is purely" arbitrary. We call to-day child-murder that which the Spartans considered a noble and unaroidable act. We call to-day highway robbery that which the bold bad baron of the Middle Ages claimed as his proud prerogative. Incest, great criminal immorality.to-day, was simple filial duty among the ancient Persians. Stealing in primitive Greece was no offence, but being caught was a capital sin. These instances could be multiplied. 
To sun up: crime is an accident, war a concomitant. We have therefore to seek for another parallel. One has suggested itself to wiser heads than mine ages agro, though, I think, it was only Dr. Engel, the statistician of the German Army, recently deceased, who has given it what I may call debatable shape. Dr. Engel, who in his great work, "The Book of Losses of the German Army," has computed the cost to a man and a horse, to a scratch, a cut, and a fever, of every feat that the German hosts have accomplished in 1870 and 1871, and who has therefore quoted, to military men of every nation, the actual price which, under given conditions, they will have to pay for any given exploit. He says :- "War is a disease in the life of a nation." In other words:- War is to the mation what illness is to the individual. Now, the ethics of discase, though probably unwritten, might justly be written and claim a legitimate place in our system of moral philosophy; and those whose profession it is to deal with disease have a complete and firmly established ethical code, according to the rules of which they-probably unconsciously; since those rules have been ingrained in them by their whole training - regulate their lives and their actions. By Engel's analogy, there is an ethical side to warfare, quod erat demonstrandum. But whether it be wise to conduct warfare according to an established ethical code, or whether, rather, the object of war-which is peace, paradoxical as it may sound - should not be accomplished as swifty as possible by any means, however foul, is the cuestion that I propose to argue. I shall not attempt to form a final conclusion, but shall leave it to my hearers to draw the balance.

One small side-issue obtrudes itself to the meditative mind. Disease is the means by which Nature, in ler all-wise scheme, elininates from the human race the weaklings, so as to maintain the race on a certain constant level of physical excellenceand perfection, or comparative perfection. Nobody will deny that. Then, granted Engel's parallel, is not war the grand scheme of Nature by which degenerate, weals, or otherwise harnful States are eliminated from the concerted action of civilised mations, and assimilated to those who are strong, vital, and beneficial in their influences? Undoubtedly it is so; but to argue that for this reason war should be carried on in the murderous fashion of, say, the ancient Persians, or the Huns, or the earliest known invaders of Europe, is to argue that we should never cure discasc, and let epidemics eat their fill unchecked, until, like the plagues of old, they exhaust the soil on which they have thriven, and dic of sheer repletion. That is surcly opposed to the very system of moral philosophy by which now the civilised part of the race governs its actions. To be sure, if we look at the race as one sentient unit, then it would almost seem we are acting unwisely in checking disease and preventing war; and $\mathrm{H}$. G. Vells, the philosopher turned novelist (or is he a novelist turned philosopher?) predicts a sad and revolting picture of the human race when those grand safeguards of all-wise Nature shall have been conquered by the human intellect, when ferers are fables of the dim past, and colds but curious memories; when doctors have ceased to trouble and bacteria are 
at rest; when man, having lost fear in his perfect security and a worldwide brotherhood, has also lost the capacity to fight, and the one kind of killing that necessarily remains (vide Wells' "Time Nachine") is a thing not to be mentioned before polite ears, the mere allusion to which would fill our descendants with as much pious horror as Marryat's American spinster experienced by the mention of the legs of the piano. To be sure, security is weakness and struggle is strength all the world over, and through untold ages; but Nature, being all-powerful no less than all-wise, will, I hope, find some safeğuard against deterioration when those provided now by disease and warfare shall have been abolished in the golden age that is to come. So far as we know from history, a nation that has lost the power to fight is doomed. Read of the behaviour of the Roman Fmpire towards the conquering Huns. How long did the Empire last? Within the next 200 years Italy was repeatedly invaded and Rome repeatedly subdued, and soon there was an end to the Roman Impire altogetherand an inglorious end.

To go back to Engel's argument, that war is to the life of a nation what disease is to the life of an individual. If this be so, then the analogy must in justice be applied to the remedies which are employed in either case. What then is the parallel of medicine as applied to the disease of nations? Medicine is either preventive or curative. The former we can safely leave out of our consideration. There is no preventive of war, granted the constitution of human beings to be as it is, for the simple reason-as mentioned before-that security means deterioration and death, and struggle means strength. If the human race is to remain as it is, or to progress in intellect and knowledge, then individuals must struggle and nations must fight. Those who advocate eternal peace and the application of arbitration in cases where history proves only the sword can speak the decisive, or what is more, the final word, advocate also the degradation of the human race to the level of pretty, soulless, two-legged animals, to whom knowledge is but a dim memory, to whom intellect is an unnecessary evil, to whom courage is an unknown quantity, because fear is an unknown quantity. In the interest of the human race, I hope that a universal and infallible preventive against war will never be discovered. The theory of evolution tends to prove that absolute security means intellectual death, and that struggle, with its inevitable result-the survival of the fittest-means strength, growth, progress, and happiness.

We have, therefore, to consider only curative medicine as applied to the disease of nations. In both components of the analogy-disease of the individual and disease of the nation-we have seen, if we compare the present with 2,000 years ago, not so much a marked improvement, but actually a radical cliange, which change, however; is due to the steady development (steady within historical times) of the idea that the individual is not a self-contained unit, but is merely part of the larger unit, nation, and in a wider sense, that the nation is not self-contained and supreme, but a component of the divine unit, humanity. This is the philosophy of altruism, of which our modern thinkers and teachers 
speak so much. The pronounced altruistic tendency of modern times shows itself in increased municipal and national life, in the voluntary subservience of the individual to the commonweal, and in the now frequently acknowledged (even by parsons) religious dogma that the true service of God is the service of man.

To return to our analogy. We all know that up to comparatively recent times the diseases of the individual were often harshly treated. To mention but a few examples: In ancient Sparta weakly children were ruthlessly killed. In mediaval times the lepers were placed beyond the pale of humanity and made to shift for themselves, and epidemics were allowed to ravage and destroy almost without check or hindrance. It is not so many decades ago that those stricken with mental discases were caged and exhibited like wild beasts. Now we bestow the greatest care upon the weakliest children, the greatest lamentations generally upon the death of the worst specimen, and to kill a deformed infant is murder -in ancient Sparta it was a godly and noble deed. We combat cpidemics with the best powers of science and skill. We surround the mentally afflicted with care and comforts. The same applies to the remedies for the national discase-warfare-that is, to the means by which war is brought to its̀ end-national recovery-i.e., peace. We necd not go back to antiquity, to the wholesale extirpation of tribes and nations, to the lot of captives of war, which was death, or, in the mildest form, lifelong slavery. Shall I remind you how VTilliam the Conqueror, in 1069, laid waste the country between Tees and Humber in so thorough a fashion that seventeen years later, in 1086 , it was counted as "waste".in the great national survey? How in 1704 Marlborough burned and ravaged Bavaria, previous to his battle of Blenheim? How in 1758 the Russians acted in the districts of the Prussian monarchy which they had invaded, until the Great Frederick laid them low at Zorndorf? How Davout governed Hamburg in 1811? Shall I draw your attention-to come to quite recent times-to the conduct of the awful six years' war between Paraguay and the Allied States of South America, 1865 to 1870, the worst war in all modern history? To mention only one incident of the war: Of the Uruguayan contingent of 12,000 men scarcely a score survived. Now we have changed all that. Prisoners of war are prisoners during war only. Women and children and the helpless ones are not molested-at least, not officially. Open towns are not shelled. Neutral territory is respected. The flag of the Ambulance is sacred. Poisoned weapons are held in righteous abhorrence. In 1870 and 71 the Germans carried on the civil administration of the French provinces they had invaded a good deal better than Napoleon III.'s officials had ever done, and the administration of the law with an impartiality-to-which the. hysterical French justices had been strangers. In 1877 the Russians protected, in the Bulgarian hamlets and villages, their enemies, the Turks, against the fanatical aggression of their allies, the Bulgarians, in a most praiseworthy and energetic fashion. Skobeleff records, through his mouthpiece, Kuropatkin, that when he occupied Adrianople 
in January, 1878 , his troops protected the mosques against sacrilege, and his sentries insisted on everyone removing his footgear when entering the sacred edifice. Fifty years before, August, 1820, the Russians had occupied the same city, had used the mosques as stables, and appropriated all that was valuable or even portable. Fvery war marks a step. In 1885 the Servians, when they invaded Bulgaria, paid conscientiously in good coin for every fowl or pig scized in farmhouses, for every glass of brandy drunk in village inns, and when the tables were turned and the Bulgarians invaded Servia, the Bulgarian soldiers and the Servian traders fraternised most cordially in the alehouses of Pirot. To come to the latest European war-that between Turkey and Greece, in 1897-we have the testimony of the war correspondents that the behaviour of the Ottoman soldiery was quite exemplary. If things continue in this wise we shall perchance hear, in the next century, of every rifle-discharge being preceded by a conciliatory caution, and every bursted shell being followed by a humble apolog ${ }^{\prime} \cdot{ }^{3}$

Scriously, we ourselves have seen, and are seeing, the gradual introduction of a purely ethical basis into warfare, not a basis of formulated rules, black upon white, arrived at at a Gonvention of Gencra or elsewhere, but a slow and certain spread of ideas, which is irresistible and will be irrevocable. It is to be hoped that nothing will be done, during the next European war, by the leaders of either side, to impele what Sorel, the Napoleonic historian, calls the "imperious march of events." I say adviscdly "impede," not " obstruct" or "prevent," for you can no more prevent the rushing torrent of popular conception than you can dam the swell of the incoming tide. You may temporarily impede it, as, throughout history, rulers, leaders, and statesmen have found out, to their cost and bitter grief.

No disquisition on the ethics of warfare can be complete without an enumeration, however brief, of the advantages and disadvantages which generally attend the sport of kings. By the way, is it not passing strange that the discase of nations should be the sport of kings? I shall pass over cursorily such disadvantages as are visible to the naked eye and form the stock-in-trade of the blatant platform-orator, with his vulgar party cry of eternal peace, his shocking examples of gore by the gallon and corpses by the ton; I shall solicit permission to dwell at somewhat greater length on such features as require a little discernment and shrewd consideration.

lirst as to disadvantages. The material ones are obvious. There is the cost in property, and the cost in life. The former is in many cases-in all, I think, excèpt where a nation be totally destroyed as a nation-balanced by the revival of trade which invariably follows the conclusion of peace. As to the latter, I rather suspect, from one or two cases that I have heard of, that the birth-rate is inclined to rise after a war, and that the loss of life is thus made good to the nation. I am no

1 This was written before the outbreak of the Spanish-American War, the conduct of which has strikingly confirmed several of the author's arguments. 
hand at statistics, and I have not the means to verify my belief; but I should be glad to hear that the Statistical Society, or some kindred body, will investigate, upon this point, all modern campaigns since, say, 1859. Another material feature is physical deterioration, owing to exposure, illness, etc. Place against this in the balance, howerer, the hardening of constitutions. War cither makes or mars a man.

Of immaterial disadvantages the unavoidable and always present brutalisation of the populace, of the rabble in particular, is the most important and the most distressing. War is always followed by an increase of crime and immorality. Can it be wondered at? Man is essentially a fighting animal, and we need not the assurance of the philosopher Nietzschke, half madman, half genius, to believe that at one period of the evolution of the species man was a " roaming wild beast." Every war is in this respect a retrograde movement in the evolution of the species. War is also a wholesale manufacturer of malcontents, revolutionarićs, and traitors-men who have fought well and.received no reward; men who have sacrificed blood, limb, or health, and have been bought off with a pittance; men on whom discipline has laid a punishing hand, perhaps undeservedly; lifelong cripples or invalids, and so forth. The care of orphans and widlows is also a prolific source of distress and discontent. But I can prove to you in a more striking manner the nature of war as a breeder of revolutionary tendencies. The murders, or attempted murders, of monarchs have often followed the conclusion of war, and, what is most strange and doubly demonstrative, of a successful war. It may' be a coincidence, but it is certainly remarkable. Orsini's attempt upon Napoleon III. (1857) took place a year after the conclusion of the war with Russia. Lincoln was murdered (1805) when the final crushing of the Southern States had just been successfully accomplished. Sultan Abdul Afiz was assassinated in 1870 after Suleiman's first Montencgrin campaign. There were two attempts upon the life of the Emperor William I. soon after 1871. The Czar Alexander II. was murdered (1881) exactly three years after the peace of San Stefano. The remarkable abduction of Prince Alexander of Bulgaria (1885) took place nine months after his brilliant victory at Slivnitza. To go back to more remote periods, the Sultan Selim III. was dethroned and assassinated in 1807, after a successful campaign against the Servian rebels. The one attempt on the life of Frederick the Great took place in the winter following his most triumphant battle, Leuthen (1758). Turning to South America, I could offer at least four instances of presidents having been murdered after the successful issue of wars, but I am loth to worry you with details. I think I have proved my case. The idea has occurred to me too Jate to investigate also the Middle Ages and authenticated antiquity ; if it were done I believe that full confirmation would be found of my theory, which is, briefly, that wars breed revolutionary tendencies, more particularly successful wars, and especially that tendency which finds its outlet in king-murder. A psychological explanation I cannot at present offer.

Another evil consequence of warare is the creation of, or the main- 
tenance of, international hatred or grudge, envy or enmity. 'The 'German soldiers in $18 \overrightarrow{70}$ revenged far less the vacillations of at weak monarch trembling for his dynasty, or the irresponsible howling of the rabble in the capital, than the terrible tales of the invasions of the First Napolcon, sixty years before, which tradition had handed down to them. Russia and Turkey have faced each other in the field ten times. One war engenders another. History is full of such instances, and the present day exhibits at least six examples: France and Germany, Russia and Turkey, Bulgaria and Servia, Spain and Morocco, China and Japan, Chili and Peru.

At length we must turn to the advantages of war. They are not quite so much on the surface. The principal matcrial advantage is the commercial and industrial prosperity, which follows peace. Of immatcrial advantages, I need but mention the instillation and promotion of all the best and most manly qualities in Man-courage, perseverance, endurance, and hope. Courage and endurance are qualities inherent in most animals, perseverance in many animals, but hope is purely human. Nan is an animal that hopes, and in the breast of a brave man only death can extinguish that divine spark. But the great benefit of war lies in its vitalising and fertilising power-the increase of national vitality, the fresh breath of national life, without which independent peoples cannot exist. None who have ever witnessed a great national rising will dispute the truth and the force of this assertion. Germany in 1870, Turkey in 1877, Chili in 1879, Bulgaria in 1885. Japan in 1894-these are our most modern instances of the most glorious aspect of warfare. Of these five, I witnessed, in $m y$ own person, three, the memory of which I count as a precious possession that shall never leave me. For if there is one feature that is divine in the history of mankind-which cxhibits so much of what is mean and despicable-it is the rising of a roused people; if there is one sight that is heavenly on this miserable earth it is the sight of a nation in arms against an aggressor.

I think I have shown that the advantages and disadvantages of war balance each other pretty equally; sometimes, perchance, the former may outweigh the latter. Who can deny, for instance, that Germany is immeasurably better in every respect for the war of ' 70 and ' 71 ? The holocausts of Wörth and Gravelotte and Paris have made themselves paid a hundredfold. Who can deny that the memories of W'aterloo, Solferino, Königgrätz, Sedan, Plevna, Slivnitza, Yalu, are, to the nations concerned, possessions-solid possessions-far beyond earthly price, and will remain so for decades, and perhaps centuries, to come? What keeps the Sick Man alive-not only alive, but strong and kicking-at the present day? 'The knowledge of Flevna. What has guided unfortunate Bulgaria through years of incredible corruption? The knowledge of Slivnitza.

I have proved, I think, firstly, that war is unavoidable; secondly, that it is not, in the long run, a disadvantage. . Therefore it is needful, firstly, to regulate its conduct according to a firmly-established and universally-accepted code; secondly, it is desirable to conduct it in as 
manner to minimise its disadvantages and bring out its advantages; never losing sight, howerer, of the great thirdly (which is also the chicf point), that it is necessary to win your war, and that by the quickest means.

In a learned disquisition on the noble game of whist I once found as Rule No. 1, in extra thick capitals, "NIake your tricks." Then came a long silence, and then followed, in small print, an enumeration of the various dodges with which skilful whist players are familiar. So in warfare. All said and done, "Win your war" is the most important, as it is the most primitive, maxim of the science of strategy-that is, drive your opponent into such a corner that he is content to have the terms of peace dictated to him. 'The rest comes a long way after.

I advocate, then, an ethical code of warfare-not so much.a written code with clauses and complications, paragraphs and perplexitics, however cunningly drawn up and solemnly agreed to, as a silent pledge of honour and faith, which can be brought about only-as I said beforeby the education and guidance of popular opinion, and an irresistible spread of ideas amongst civilised nations.

Granted the desirability of this ethical code, can anyone maintain that the ruthless destruction of homesteads (cxcept, of course, where the necessities of tactics demand their absence), the burning of villages, the poisoning of wells, the seizure of peaceful hostages, the contributions laid on unoffending citizens, can find a place in such a code? Is, or was, there not an established code of duelling, although thrusts that were not within the hard and fast lines of the code were often far more efficacious? Do we not conduct our criminal trials in accordance with a very severe cole, from which, to mention only an instance, ethics demanded and obtained the banishment of torture? Let war be a noble rivalry of skill and science, courage and endurance, with a chivalrous abhorrence of foul means. I maintain that that commander must be a poor one who cannot conduct a war to its end, quickly and effectively, without the latter, when modern inventive genius has placed into his hands such long-range rifles and such quick-firing guns as we now possess, not to mention balloons, electricity, and many other triumphs of practical science. I confess readily that centuries ago, when fircarms were in their infancy, and telegraphy and railways were unknown, the wholesale devastation of provinces and destruction of towns was occasionally demanded imperatively by the necessities of strategy. I have in my mind the 'Thirty Years' War, 1618-48. Then rifles were so heavy and cumbersome as to necessitate a prop; their loading was the labour of several minutes; their range was smaller than that of arrows, and their aim much more uncertain. Then preserved food was unknown; then electricity and steam were undiscovered slumbering giants. I3ut to act now as did then Tilly and Vallenstein, and the Swedish Praying King, would be to grive the lie direct to all the noble achievements of the mechanical geniuses of two and a half centuries.

To conclude, every nation pays a price for her existence, and a greater price for her greatness, By a conduct of war, such as laid down, 
the material and moral cost of war would be lessened to both victor and defeated; the end would be the same; and the necesary struggle for existence-without which neither nations nor individuals can livewould, by a preponderance of the advantages which attend warfare, be transformed into something almost akin to a blessing in disguise.

Captain A. V. J. Cowell (Rifle Brigade):-I must apologise, Sir, for speaking, because I am apparently the youngest officer present, but there are three points I should like to touch upon. The first is, the lecturer in his synopsis says that the individual is not a unit, but only the component of a unit. Well, I humbly submit he is a unit. The other day I came back on board the "Aroca" with a certain number of men who were being sent home for recommittal; a very sad thing. They were bound to undergo imprisonment, and therefore had little to fear, and they therefore began to give trouble. I happened to be in command of the drafts, and went down and tried to apply a knowledge of human nature in order to keep them quiet. I pointed out that they were what were called prisoners in cells, and therefore a particular discipline was applicable to them, and that discipline was that if they gave trouble they would be flogged. Directly those men heard that in all probability they would be floged they behaved then:selves. , The second point $I$ wish to allude to is where the lecturer says that war should be a noble rivalry of skill and science, courage and cndurance, with a chivalrous abhorrence of foul means. That is all very nice and pretty, but I submit, Sir, in these days when we have got to fight to win, that it will not take place. Nothing would strike me with less surprise any morning than to hear that our telegraphs had been cut by spies, and our bridges and all our means of communication from one part of England to the other blown up-that the first intimation of war we should have would be to hear that everything that had to clo with our mobilisation had been destroyed. The third point I should like to draw attention to is the necessity of carefully preserving the health of the men, a duty which, in India at least, has been disgracefully neglected by the authorities; and which materially affects the morale of the men.

Lieut.-General Lord Williay Semour:-There is only one point in the exceedingly able lecture we have just heard from Captain Herbert which I should like to ask his opinion upon. Discussion on this subject is exceedingly difficult, and I will therefore confine myself to one question relating to the great war between the Northern and Southern States of America from $1 S 61$ to 1S64. I would ask Captain Herbert under what category he would place that war, a war very bloody and full of disease, I believe involving the loss of more men than ensued during the whole of the Peninsular War? Whether that war between two sections of a nation, however far separated, comes under the category that he has in several of these paragraphs dilated upon, namely, the probable fate of the race if the disease was stamped out, and the fate of the nation on the abolition of war? Also, whether after that war was finished you could look upon it that the material advantages and the revival of trade and industry was promoted by that war?

Lieut.-Colonel $A$. T. WINTLE, late R.A. (Bengal) :-It will always be a moot question what should be done in war-time, and I do not think it is srenerally known that the Duke of Wellington, when he was General Wellesley, in India, ordered, in some instances, forts to be taken by escalade, and all the garrison, if desperate resistance was made, to be destroyed. That was in 1803. One of the Mahratta chiefs, writing to another, said:- "These English are a strange people, and their general a wonderful man. They came in here this morning, looked at the Pettah wall, walked over it, killed all the garrison, and returned to breakfast. Who can withstand them?" . On the other hand, we hear of the Indians in Scnora, of whom it has been said:- "Their character is open, teachable, 
and loyal to the white man, that they are fearless and capable of hearing every hardship, marching for wecks with a little bag of pinola (ronsted flour) on their backs, making daily 50 or 60 miles. Of their courage many examples are given. In war their humane character shows itself in its full light, and prisoners are not killed, as in many other tribes, but mosily set free." The lecturer referred to the way war was carricd on 2,000 years ago; but if you take the Greck accounts of what happened in India in those days, you will find there were many instances in which the Indians were not supposed to track their opponents, as you can read in the Laws of Mena, in which it is also said "There has been declared the blameless primaval law for military men." In considering war, I think we ought to consider whether there is any good in artillery-will it tend to any result? For instance, using machinery. Now there are undoubted signs of national decay going on in England, and to the Eastern nations this must have been apparent hundreds of years ago. Lord Bacon said that "In the youth of a State, arms do flourish; in the middle age of a State, learning; and then both together for a time; in the declining age of a State, mechanical arts and merchandise." Can that be applied to the art of war? I think it was Gray, the poet, who said :-

"Ill fares the land to hastening ills a prey,

Where wealth increases and men decay."

There is no doubt about the wealth increasing in this country, and men decaying too; that is proved by the decay of the teeth. Vico, inthesixteenthentury said:"A corrupted people is more cruel in its latest than in its earliest stage of civilisation. In the carlier stage it is caused by nature, in the latter by crect. The first was angry but generous; an enemy might defend hinself or fly. The laterstage, not less cool, is cowardly and perfidious; it is in pretending to save that it loves to strike." That seems to me the way that civilians carry out war. I will give you an instance. In South Africa we have had to contend with the Boers and Matabeles, pastoral races, and now we have sent our veterinary surgeons amongst them to inoculate their cattle, with the result that their cattle have died; and that is going on not only there, but in India; Burmah, and all sorts of places. One of the speakers has remarked about the health of the troops, and that, I consider, is the first question of the day. Napoleon said:- "Health" is indispensable for war, and nothing can replace it." And Robert Jackson, a well-known surgeon in the Peninsular War, said:-"The possession of health gives power to the arm and courage to the heart, in confidence of power. The increased activity of the same quantity of physical force multiplies effect; but power and activity are incompatible with feeble health. A knowledge of the causes therefore which preserve, restore, and improve this condition, is of primary importance. It clemainds the first attention in the present times, for the British nation cannot expect to number soldier for $\mathrm{s}^{-1}$-Jier with the French Republic; but the British soldier decidedly possesses super.ur power in the power of action. This is an object of military study. It implies a correct knowledge of the physical, and even of the moral qualities of the soldier. But as the perfection of the physical qualities depends upon perfection of health, it demands a minute attention, for it is the cardinal hinge of effect in armies." Carlyle said that there was stupidity intellectual and stupidity moral, and I an inclined to think that there is disease physical and disease intellectual as well. The first speaker spoke of the enemies within our own gates. That seems to be going on everywhere, and I am afraid we shall find that sooner or later in India the whole nation will rise. That has been prophesied by military men years ago. Sir Charles Napier referred to it. It is because we are deliberately going to work to upset their old-established customs. We have interfered with their religion, and that is a thing that has not been considered sufficiently by our soldiers. In India the Hindoos take upon themselves the maintenance of Religion, and, roughly speaking, we may say the Chinese have taken upon thenselves the nuantenance of Reason, and we at the present time have got nothing else but 
law to trust to. What possible chance have we in trusting to law, which twists ahout and is contradictory, when we go agatinst two nations who are guided by Religion and Reason? I could say more, but I think I have said enough for the purpose.

Captain W. V. HersekT, in reply, said:-Of course, a code of ethics in warfare could obtain only between nations of an equal, or tolerably equal, state of civilisation ; that stands to reason. There can be no code of cthics, for instance, between Zulus and English ; but there can be, I maintain, a code of ethics between the Chinese and Japanese. They are tolerably alike, except that the civilisation of China is very much older; the civilisation of Japan is a more musluroom growth. It may have grown more in twenty years than Chinese civilisation has grown in two thousand. I remenber distinctly my first days in England. It was at the time, I think, of the Zulu War, and there was a most striking instance of the boy's calling in the streets one day "Shocking murder of a whole British regiment"-it was at Insandlwana. A few weeks after it was "Grand slaughter of the Zulus!" That is the ethics of warfare between a civilised nation and a savage tribe. General Lord William Seymour spoke of the Civil War in America. I maintain that the Civil War of America was a necessary step in the imperious march of the erents of history; as Sorel expresses himself ; and I also maintain that the United States of Americal would be worse off at the present moment if there had been no civil war, for they would have been split up into two parts, undoubtedly; and I think, equally undoubtedly, those two parts would have made war upon each other or been attacked simply from the outside, and possibly the weakest would have gone to the wall to an outside nation. I have no hesitation in saying that if the Civil War of America had not taken place, and there had been a split into two republies, the Southern would have suffered severely at the hands of Mexico. Mexico was waiting to avenge herself for the American-.Iexican War, in which she had been badly treated, and no doubt the province of Texas would be Mexican in these days. There was a strange case affecting the question of prisoners of war in which I wondered what was the right thing to do. General Douay was taken prisoner at Sedan, and he gave his word of honour he would travel by himself as best he could to a certain place, Pont à Mousson, I think, and gave his word of honour to surrender himself there on a certain day. He wore the clothes of a Frenchman of the lower class, and he surrendered himself at Pont it Mousson at the railway station to a German officer. Whether it was that this German officer did not speak French sufficiently well,or that be was suffering from an overdose of the remedy against influenza, I do not know; in any case, the German officer, secing this ragged fellow, said, "Go to the Devil!" General Douay considered that he had complied with the term:s of his parole and escaped, and was next heard of in Paris, where he took an active part in the defence of the eity. Now, would the Germans have been justified, when they next captured him, in shooting him as a man who had broken his parole? Of course they did not, for they never captured him until after peace was made, and then all things were forgiven. But that is a question I should like to have answered. With regard to the seizure of hostages. It is recorded in a book which I have read-the diary of some German private soldier-that when the mayors of many French villages were required to surrender themselves as hostages, they said, "No, I am busy; I have this, that, or the other thing to attend to; but I have a dear mother-in-law, and you are quite welcome to seize her." Of course this hind of seizure of hostages is a small thing. What I was thinking of was the seizure of twenty or fifty peaceful inhabitants, as the Russians did in Turkey in 1577, and carting them more than a thousand miles awny into the interior of Russia. That I think was a brutality. It is the same with regard to contributions. A contribution of 50,000 francs haid upon a village for a few shots fired is certainly better than exterminating the village; but the regular contributions levied by the Germans shortly after Sedan, I forget of how 
many millions, on a whole French province or district, which included Sedan, for some imaginary harm done to German shipping, was, I think, entirely unnecessary. The Germans got all they wanted at the end of the campaigrn. It may be said that $I$ an a lover of war, but $I$ cannot say that $I$ an. What $I$ maintain is that war is unavoidable, and therefore it is just as well to make it as little unpleasant as possible to the peaceful population that can have no concern with the war. We must also not forget that within the present century there lave been a great many so-called diplomatic wars which no human being knew what they were being fought about. As you remarked in my last lecture, who on earth knew then or knows now the cause of the war of 1S66? Nobody can tell. Perhaps the only man who can is Bismarck, and he has not enlightened us. Necessarily in such a war the population can have no concern, arid that $I$ take it is all the more reason why the population should be left alone. I think it was the third speaker, Colonel Wintle, who said something about the American Civil War. I woukd refer the speaker, or anybody clse who likes to study the subject, to the war between Paragualy and the Allied States of South America. I think this war beats, in sheer horrors, in the expense of human life, and in brutality, any other war, including the American Civil War. I have told you already that the Uruguay contingent of some 12,000 men were swept off the face of the earth all but twenty people. The whole country of Paragruay, a country of the size of England, contained at the cnd of the war, I was informed by an Argentine soldier, less than l,000 human beings, and a few dogs and cats. The whole country had been devastated, and Assuncion, the capital, of 20,000 inhabitants, was positively emptied.

The Ciniryan (Colonel Lonsdale Hale) :- "The Ethics of Warfare" under the title of "The Usages of War" was the subject of enquiry by an Intermational Conference held at Brussels in 1874 on the initiative of the then Emperor of Russia. At that conference each nation of Europe was represented by one or more distinguished soldier, and it was my good fortune to be there as assistant military secretary to the British representative, the late General Sir Alfred Horsford. The conference lasted six weeks, and every branch of the subject was gone into fully. The result showed that on general questions it was quite possible to arrive at some agreement, but that on details there was a decided tendency to becone unpractical. As an instance, the conference, agreed that if a prisoner attempted to escape and when challenged did not desist he might be fired at; but at the conference the question came up on three different occasions, the point at issue being whether the challenge should be given once or three times before the man was fired at. Common sense, however, carried the diny in fisour of a single challenge. Further, on the usages of war there was a marked difference of opinion between nations possessing large armies and those which had small armies only and relied on aid from the civilian population. It must further be remembered that the ethics of an army in the field is a reflector of the ethics of the nation to which it belongs, and therefore agreement is possible only between armies of nations whose national ethics is similar in character. As regards contributions levied in war on offending districts, and the taking of hostages, these woukd seem to be obvious and justifiable measures for self-protection; and with respect to poisoning wells, so long as this is done openly and the fact notified in some way to those who would use them, there seems to be nuthing more to be said against this forbidden practice than against the permitted practice of depriving the eneny of grood water supply by filling in wells or by cutting off the good water as the Germans did at Metz and Paris and reducing their enemy's water supply to the sewarge-receiving Moselle and Seine. If it is permissible to slarve one's enemy by denying him solid food, it seems equally permissible to starve him by denying him liquid food. We have to thank Captain Herbert for the interesting lecture to which we have listened this afternoon. 